The Bulletin of the Dnipropetrovsk university.

Series: Management of innovations

Issue 7, Volume 24 (2016)

DOI: $10.15421 / 191625$

Received: 26 Oct 2016

Accepted: 12 Dec 2016

Published: 25 Dec 2016

\title{
Планування інвестицій в інноваційну продукцію на основі матриці інноваційного потенціалу регіону
}

\begin{abstract}
Ефективне керування інноваційним процесом для виробництва інноваційної продукції передбачає обґрунтування джерел, визначення обсягів і об'єктів фінансування інноваційних розробок. Оскільки один із важливих елементів керування інвестиційним забезпеченням інноваційного розвитку - планування вартості та витрат на інноваційну продукцію, обраний напрям дослідження вважаємо актуальним. Мета роботи - характеристика методу визначення обсягів інвестицій в інноваційну продукцію за ї̈ типами і підприємствами на основі матриці інноваційного потенціалу регіону для формування оптимального інвестиційного портфелю.

Перелічено основні види форсайтних досліджень науково-технічного розвитку, які проведені в Україні. Зроблено висновок, що не зважаючи на множинність варіантів такого розвитку, його напрями поряд з іншими факторами обмежені фінансовим забезпеченням виробництва інноваційної продукції, складник якого - визначення потрібних обсягів та об'єктів для інвестування.

Охарактеризовано метод відбору видів інноваційної продукції як об'єкту для інвестування. Для відбору інвестиційних об'єктів визначають перелік пріоритетних для регіону критичних технологій та інноваційних підприємств, оцінюють інвестиційні ризики на різних стадіях виробництва інноваційної продукції, розраховують дисконтований дохід і ціни ризиків, розв'язують задачу оптимального розподілу інвестицій за типами продукції і підприємствами із урахуванням дисконтованого доходу й ціни ризиків.

Новизна дослідження полягає у алгоритмізації відбору пріоритетних для інвестування інноваційних технологій на основі матриці інноваційного потенціалу регіону.

Результати дослідження можуть бути застосовані для формування інвестиційного портфелю, що містить найбільш перспективні 3 економічного погляду інноваційні технології.

Перспективний напрям для подальших досліджень - здійснення порівняльного інвестиційного портфельного аналізу інноваційних виробництв для різних галузей діяльності на основі запропонованого алгоритму.
\end{abstract}

Ключові слова: фінансування інновацій; матриця інноваційного потенціалу регіону; інноваційні підприємства; інвестиційні ризики; оптимальний розподіл інвестицій.

‡ Оксана Вячеславівна Марухленко, Київський університет імені Бориса Грінченка, Київ, Україна, тел.: +380994307248, ksushik1980@yandex.ua

JEL Classification D92. 


\section{Планирование инвестиций в инновационную продукцию на основе матрицы инновационного потенциала региона}

О. В. Марухленко

Киевский университет имени Бориса Гринченко, Киев, Украина

Эффективное управление инновационным процессом для производства инновационной продукции предполагает обоснование источников, определение объемов и объектов финансирования инновационных разработок. Поскольку один из важных элементов управления инвестиционным обеспечением инновационного развития - планирование стоимости и затрат на инновационную продукцию, выбранное направление исследования считаем актуальным.

Цель работы - характеристика метода определения объемов инвестиций в инновационную продукцию по ее типам и предприятиям на основе матрицы инновационного потенциала региона для формирования оптимального инвестиционного портфеля.

Перечислены основные виды форсайтных исследований научно-технического развития, проведенные в Украине. Сделан вывод, что несмотря на множественность вариантов такого развития, его направления наряду с другими факторами ограничены финансовым обеспечением производства инновационной продукции, составляющая которого определение необходимых объемов и объектов для инвестирования.

Охарактеризован метод отбора видов инновационной продукции как объекта для инвестирования. Для такого отбора определяют перечень приоритетных для региона критических технологий и инновационных предприятий, оценивают инвестиционные риски на различных стадиях производства инновационной продукции, рассчитывают дисконтированный доход и цены рисков, решают задачу оптимального распределения инвестиций по типам продукции и предприятиями с учетом дисконтированного дохода цены рисков.

Новизна исследования заключается в алгоритмизации отбора приоритетных для инвестирования инновационных технологий на основе матрицы инновационного потенциала региона.

Результаты исследования могут быть применены для формирования инвестиционного портфеля, содержащего наиболее перспективные с экономической точки зрения инновационные технологии.

Перспективное направление для дальнейших исследований проведение сравнительного инвестиционного портфельного анализа инновационных производств для различных отраслей деятельности на основе предложенного алгоритма.

Ключевые слова: финансирование инноваций; матрица инновационного потенциала региона; инновационные предприятия; инвестиционные риски; оптимальное распределение инвестиций.

\section{Planning of investments into innovative products based on the matrix of innovative potential of the region}

\author{
O. V. Maruhlenko \\ Borys Grinchenko Kyiv University, \\ Kyiv, Ukraine
}

Effective management of innovative process for the manufacturing of innovative products implies the substantiation of sources, determining the volumes and objects for financing the innovations. As one of the most important elements in managing the investment provision for innovative development is planning the cost and expenditures for innovative products, we consider the chosen direction of present research to be relevant.

The aim of present work is a characteristic for the method of determining the volume of investment into innovative products by the type of products and enterprises based on the matrix of innovative potential of the region for formatting of optimal investment portfolio.

Here we enumerate the basic types of foresight research into scientific and technological development, which were conducted in Ukraine. The conclusion is drawn that despite the multiple variants for such a development, its directions, along with other factors, are limited by the financial means for producing innovative products whose component is determining the required volumes and objects for investing.

We characterized a method for selecting the types of innovative products as an object for investment. In order to choose investment objects, the list of critical technologies and innovative enterprises that have priority for the region is defined; investment risks at various stages of manufacturing innovative products are assessed; discounted income and price of risks are calculated; the problem on optimal allocation of investments by the types of products and enterprises is resolved with regard to the discounted income and price of risks.

The novelty of present research is in the algorithmization of selecting the innovative technologies that have priority for investment, based on the matrix of innovative potential of the region.

Results of the study might be applied to form an investment portfolio that would contain the most promising innovative technologies from the economic viewpoint.

Promising topics for further research is conducting a comparative portfolio analysis of innovative enterprises for various fields of activity based on the proposed algorithm.

Keywords: financing of innovations; matrix of innovative potential of the region; innovative enterprises; investment risks; optimal allocation of investments. 


\section{Вступ}

фективне керування інноваційним процесом для Е виробництва інноваційної продукції передбачає обґрунтування джерел, визначення обсягів і об'єктів фінансування інноваційних розробок. Один із важливих елементів керування інвестиційним забезпеченням інноваційного розвитку, конкурентоспроможністю на будьякому рівні, починаючи з невеличкого підприємства i закінчуючи угрупуваннями держав, - це планування вартості та витрат на інноваційну продукцію. Вартість інновацій - міра рівня R \& D інвестицій, необхідних для створення винаходу в конкретній галузі або сегменті промисловості. Ї̈̈ величину використовують у якості інструменту планування технології, зокрема, для підтримки інвестиційних рішень керуючих компаній з розширення у нових областях (Bigwood, 2000) [1].

Kharchenko, Alpeeva, \& Ovcharova (2014) наголосили, що стратегічний розвиток конкурентоздатних регіонів визначається не тільки зростанням валового регіонального продукту, але i також максимізацією випуску інноваційної продукції, рівнем зайнятості, інформаційного і, як наслідок, освітньоінноваційного потенціалу [2].

Водночас, системне обмеження доступу до фінансових ресурсів, ринків і мережі знань, недосконалість планування інвестиційних ресурсів сприймають як обмеження інноваційного потенціалу в регіоні. Погіршує ці проблеми поширення відсутності довіри між суб'єктами і установами по всій інноваційній системі, перешкоджаючи потенціал колективних дій (Lowitt et al., 2015) [3].

Визначення об'єктів та обсягів інвестиційних вкладень у інноваційну продукцію стало необхідним фінансовим складником інноваційно-інвестиційного процесу. Його обов'язковий елемент - планування - забезпечує стратегічний розвиток конкурентоздатних регіональних економічних систем.

Вивченню окремих боків планування інвестиційного забезпечення інноваційного розвитку окремих суб'єктів господарювання і регіонів присвячено чимало наукових праць. У якості засобу планування інвестицій в області стратегічного управління і сприяння процесу прийняття рішень в умовах невизначеності застосовують метод планування сценаріїв і багатокритеріальний аналіз рішень (Hanafizadeh, Kazazi, \& Jalili Bolhasani, 2011)[4], для кластеризації міст відповідно до їх схожості споживання, рівня добробуту, темпів зростання і порівняння їх 3 потенціалом ресурсів - методи інтелектуального аналізу даних (Yuregir, \& Sagiroglu, 2016) [5]. Воднораз вибір інноваційних об'єктів та вартості інвестицій у інноваційну продукцію в територіальному розрізі має певну специфіку. Kleibrink, Gianelle, \& Doussineau (2016) наголосили, що для реалізації комплексного підходу під час планування інвестиційної стратегії в області інновацій і територіального розвитку потрібен моніторинг територіальної інноваційної політики на різних рівнях управління для сприяння розвитку $\mathrm{i}$ фінансування політики спеціалізації [6]. А оскільки інтереси інвесторів суперечливі, для залучення зацікавлених інвесторів цей моніторинг має бути послідовний, щоб показати розвиток подій в рамках пріоритетних областей і забезпечити логіку втручання і контролю (Kleibrink, Gianelle, \& Doussineau, 2016) [6]. Здійснення моніторингу допомагає вивчати, ідентифікувати, оцінювати імовірність ризиків і їх можливий вплив, керувати ними на усіх етапах життєвого циклу від ідеї до впровадження нововведень, підготувати загальний план дій по боротьбі з ними (Lee-Mortimer, 1995) [7]. Розгляд життєвого циклу проектування виробів з урахуванням різних вимог до знань на стадіях концептуального проектування, конфігурації компонентів, планування процесу і планування виробництва та їх пов'язування з інженерними, складовими, технологічними й виробничими характеристиками допоможе розробнику відстежувати необхідні знання для реалізації інноваційного продукту (Zhang et al., 2016) [8].
Економічне планування підвищує ефективність інвестиційних рішень для стимулювання економічного зростання й вироблення політики розвитку. Зміни останньої на основі принципу справедливості передбачають децентралізацію методів і механізмів планування, формування міцного зв'язку між інноваційною політикою, плануванням інвестицій та реалізацією інноваційних програм, а також поширення адміністративного потенціалу серед широкого спектру державних і приватних установ для генерації, розробки і здійсненні інвестиційної політики і проектів (Rondinelli, 1978) [9].

Досягти конкурентних переваг шляхом оптимізації маркетингової і технічної підтримки наближення інновацій до потреб клієнтів можна застосовуючи матричний підхід, наприклад матрицю продуктових нововведень (product innovation matrix) (Lee-Mortimer, 1995) [7].

Аналіз теоретичних і прикладних досліджень інвестування інноваційних процесів свідчить про створений фундамент для планування цих процесів, проте ефективні методи визначення вартісних характеристик впровадження нових технологій не розроблені. Із урахуванням цього вважаємо за доцільне розробку методу визначення пріоритетних напрямків інвестування у інноваційний розвиток на основі аналізу інноваційної діяльності регіонів і за його результатами формування інвестиційного портфелю, що містить найбільш перспективні з економічного погляду інноваційні технології.

\section{Постановка завдання}

ета роботи - характеристика методу визначення обсягів М \інвестицій в інноваційну продукцію за ї̈ типами іпідприємствами на основі матриці інноваційного потенціалу регіону для формування оптимального інвестиційного портфелю.

\section{Методи та інформаційні джерела дослідження}

етодологічну основу дослідження склали загальнонаукові \Мй спеціальні методи. Абстрактно-логічний метод застсовано для алгоритмізації відбору пріоритетних для інвестування інноваційних технологій на основі матриці інноваційного потенціалу регіону; статистико-економічний та табличні методи - для вивчення інноваційної активності й інноваційного потенціалу промислових підприємств України, розподілу неінноваційних підприємств за причинами, що перешкоджали здійсненню інновацій протягом 2012-2015 pp. \%; метод Ньютона, реалізований у надбудові Microsoft Excel «Пошук рішення», - для розв'язку задачі оптимального планування інвестицій у виробництво інноваційної продукції.

Інформаційні джерела дослідження - дані Державної служби статистики України, Державної служби інтелектуальної власності, доповіді міжнародних організацій, експертні інтерв'ю, результати науково-дослідних робіт.

\section{Результати}

ермін «інновація» в широкому і вузькому значеннях являє Т собою сприйняте системою нововведення (новацію) і як результат інтелектуальної діяльності впроваджене в практику. Людина-інноватор і / або сформовані нею організаційні форми взаємодії, пов'язані 3 інноваційними процесами, - це суб'єкти інноваційної діяльності.

Процес виробництва інноваційної продукції (технічних виробів, систем і технологій різного призначення) можна уявити послідовністю чотирьох стадій: завершення НДДКР, дослідне виробництво, дрібносерійне виробництво, промислове виробництво. При цьому кожній стадії відповідає певний стан продукції: дослідний зразок, дослідна партія, серійна або промислова продукція. 
Важливий момент, що визначає ефективність інвестицій, вибір технології, у межах якої заплановано організацію виробництва інноваційної продукції.

Останнім часом в Україні проводять форсайтні дослідження (світова практика свідчить, що протягом останнього десятиріччя застосовують три основні методології Форсайта: метод Дельфі, метод критичних технологій, метод панелей або цільових груп експертів). Їх початок покладено Державною програмою прогнозування науково-технічного розвитку на 2004-2006 рр., у межах реалізації якої визначено пріоритетні напрями науково-технічного розвитку. Але фінансування цієї Програми було скорочено майже вдвічі та їі реалізацію у 2006 р. призупинено. У 2007 р. Постановою Кабінету міністрів України (КМУ) від 11.09.2007 р. № 1118 затверджено Державну програму прогнозування науковотехнологічного розвитку на 2008-2012 рр. Базовою організацією, яка повинна була забезпечити організаційний супровід виконання Програми, визначено Український інститут науково-технічної і економічної інформації (УкрIHTEI) [10]. Сформовані експертами та схвалені Науково-технічною радою УкрIHTEI Програми та Переліки критичних технологій надіслано до КМУ для врахування під час формування Урядом державного замовлення на науково-технічну продукцію та інноваційні проекти. Водночас зазначені Переліки було надіслано галузевим міністерствам, обласним і міським державним адміністраціям для можливого впровадження критичних технологій і розміщено на офіційній web-сторінці УкрIНTЕІ. Згідно з Постановою КМУ від 22.06.2011 р. № 704 «Про скорочення кількості та укрупнення державних цільових програм» зазначена програма втратила чинність. Результати проведеного УкрIHТЕІ форсайтного дослідження покладено в основу Закону України від 08.09.2011 р. № 3715 «Про пріоритетні напрями інноваційної діяльності в Україні», яким визначено стратегічні пріоритетні напрями інноваційної діяльності на 2011-2021 рр.; Постанови КМУ України від 07.09.2011 р. № 942 «Про затвердження переліку пріоритетних тематичних напрямів наукових досліджень і науково-технічних розробок на період до 2015 р.», Постанови КМУ від 12.03.2012 р. № 294 «Деякі питання визначення середньострокових пріоритетних напрямів інноваційної діяльності загальнодержавного рівня на 2012-2016 рр.».

Ступінь розвитку в регіоні інноваційних технологій безпосередньо залежить від відповідного фінансування виробництва інноваційної продукції, ВН3, що забезпечують підготовку наукових кадрів і виконують наукові дослідження, кількості інноваційних підприємств і різноманіття напрямків їх діяльності, наявності в регіоні підприємств і організацій, які $\epsilon$ споживачі цієї продукції і які здатні надати фінансову підтримку профільним інноваційним підприємствам [11; 12].

Отже, в державі сформовано декілька фосайтних варіантів науково-технічного та інноваційного розвитку регіонів, але не зважаючи на їх множинність, його напрями поряд з іншими факторами обмежені фінансовим забезпеченням виробництва інноваційної продукції, складник якого - визначення потрібних обсягів та об'єктів для інвестування.

Нижче охарактеризовано запропонований нами методичний підхід до визначення об'єктів для інвестування в інноваційну продукцію. Розв'язання задачі формування ефективного інвестиційного портфелю можливе шляхом застосування послідовного алгоритму відбору, суть якого зведене до таких дій.

Під час планування обсягів інвестицій у виробництво інноваційної продукції спочатку необхідно оцінити інноваційний потенціал регіону. Вирішити цю проблему можна таким чином.

По-перше, встановлюють відповідність між переліком критичних технологій державного рівня та організаціями регіону, які виконують наукові дослідження і підготовку наукових кадрів за цими технологіями, інноваційними підприємствами регіону, що випускають інноваційну продукцію, і споживачами цієї продукції в регіоні, інших регіонах України, країнах ближнього і далекого зарубіжжя.

По-друге, в результаті цих дій формують матрицю інноваційного потенціалу регіону (МІПР), яка містить тільки ті критичні технології, за якими в регіоні здійснюють розробку і виробництво інноваційної продукції. Опосередковано це вказує на присутність профільних інноваційних підприємств у регіоні.

Практична апробація запропонованого нами методу підходу здійснено на основі аналізу даних інноваційної активності промислових підприємств України. За результатами обстеження виявлене наступне.

у 2015р. промислові підприємства впровадили 3136 інноваційних типів продукції, із яких 548 - нові виключно для ринку, 2588 - нові лише для підприємства. Серед загальної кількості впровадженої продукції 966 - нові типи машин, устаткування, приладів, апаратів тощо. Найбільшу кількість інноваційних типів продукції впроваджено на підприємствах Тернопільської (27,2% загальної кількості впроваджених типів інноваційної продукції), Запорізької (12,7 \%), Львівської (8,0%), Харківської (6,6\%) областей і м. Києва (14,4\%); за типами економічної діяльності - на підприємствах із виробництва машин і устаткування, не віднесених до інших угруповань (22,9\%), паперу й паперових виробів (16,2\%), харчових продуктів (11,3\%), металургійного виробництва (5,5%) (табл. 1).

Кількість упроваджених інноваційних технологічних процесів (нових або вдосконалених методів обробки та виробництва продукції) становила 1217, найбільше з яких впровадили підприємства Харківської (17,4\%), Сумської (15,2 \%), Запорізької (9,4 \%), Дніпропетровської (6,3\%) областей та м. Києва (12,5\%); за видами економічної діяльності - на підприємствах із виробництва машин і устаткування, не віднесених до інших угруповань (25,3\%), інших транспортних засобів (12,3\%) і харчових продуктів (7,8\%). Серед загальної кількості впроваджених інноваційних технологічних процесів 458 маловідходні, ресурсозберігаючі.

У 2015 р. 570 підприємств реалізували інноваційну продукцію на 23,1 млрдгрн. Серед таких підприємств 37,4\% реалізували продукцію за межі України, обсяг якої становив 10,8 млрд грн. Кожне четверте підприємство реалізовувало продукцію, що була новою для ринку. Обсяг такої продукції становив 7,3 млрд грн, майже дві їі третини підприємства експортували. Значна кількість підприємств (86,0 \%) реалізовувала продукцію, яка була новою виключно для підприємства. ІІї обсяг становив 15,8 млрд грн. Кожне третє підприємство реалізувало за межі України 40,1 \% такої продукції.

Для впровадження нововведень 181 підприємства придбали 1131 нову технологію, із яких 66 - за межами України. Серед загальної кількості технологій 439 придбано із устаткуванням, із яких 43 - за межами України; 393 - як результат досліджень і розробок; 120 - за договорами на придбання прав на патенти, ліцензіями на використання винаходів, промислових зразків, корисних моделей; 37 - за угодами на придбання технологій та ноу-хау; 129 - разом із цілеспрямованим прийманням на роботу кваліфікованих фахівців.

У результаті інноваційної діяльності 9 підприємств створили нові технології, із яких 98 було передано іншим підприємствам, зокрема 20 - за межі України. У 2015 р. інноваційною діяльністю в промисловості займалися 824 підприємства або 17,3\% обстежених промислових.

Серед регіонів вищою за середню в Україні була частка інноваційно активних підприємств в Миколаївській, Харківській, Кіровоградській, Івано-Франківській, Запорізькій, Херсонській, Сумській, Одеській, Львівській і Тернопільській областях (табл. 2). 
Таблиця 1

Інноваційна активність промислових підприємств в Україні

\begin{tabular}{|c|c|c|c|c|c|c|c|c|c|}
\hline \multirow[b]{3}{*}{ Рік } & \multirow{3}{*}{$\begin{array}{c}\text { Питома вага } \\
\text { підприємств, } \\
\text { що займалися } \\
\text { інно- } \\
\text { ваціями }\end{array}$} & \multirow[b]{3}{*}{$\begin{array}{c}\text { Загальна } \\
\text { сума } \\
\text { витрат }\end{array}$} & \multicolumn{7}{|c|}{ У тому числі за напрямами } \\
\hline & & & \multirow[b]{2}{*}{$\begin{array}{c}\text { Дослід- } \\
\text { ження і } \\
\text { розробки' }\end{array}$} & \multicolumn{2}{|c|}{ зних } & \multirow[b]{2}{*}{$\begin{array}{l}\text { Прид- } \\
\text { бання } \\
\text { нових } \\
\text { техно- } \\
\text { логій }\end{array}$} & \multirow{2}{*}{$\begin{array}{c}\text { підготовка } \\
\text { виробництва } \\
\text { для впро- } \\
\text { вадження } \\
\text { інновацій }\end{array}$} & \multirow{2}{*}{$\begin{array}{c}\text { придбання } \\
\text { машин та } \\
\text { обладнання } \\
\text { пов'язані } \\
\text { з упрова- } \\
\text { дженням } \\
\text { інновацій4 }\end{array}$} & \multirow[b]{2}{*}{$\begin{array}{c}\text { інші } \\
\text { витрати }\end{array}$} \\
\hline & & & & $\begin{array}{l}\text { Внут- } \\
\text { рішні } \\
\text { НДР }\end{array}$ & $\begin{array}{l}\text { Зов- } \\
\text { нішні } \\
\text { НДР }\end{array}$ & & & & \\
\hline & $\%$ & \multicolumn{8}{|c|}{ тис.грн. } \\
\hline 2000 & 23,4 & 79679,0 & 7522,6 & $\mathrm{X}$ & $x$ & 520,0 & 2659,8 & 50877,6 & 18099,0 \\
\hline 2001 & 16,3 & 117711,4 & 11991,1 & $\mathrm{x}$ & $\mathrm{x}$ & 1225,4 & 6907,5 & 53998,9 & 43588,5 \\
\hline 2002 & 16,3 & 237890,7 & 8826,2 & $\mathrm{x}$ & $\mathrm{x}$ & 16505,7 & 8930,5 & 152895,0 & 50733,3 \\
\hline 2003 & 33,0 & 283323,6 & 10943,4 & $\mathrm{x}$ & $\mathrm{x}$ & 9579,9 & 31798,9 & 137130,3 & 93871,1 \\
\hline 2004 & 41,5 & 847984,2 & 77308,0 & $\mathrm{x}$ & $\mathrm{x}$ & 7933,6 & 263622,7 & 433143,2 & 65976,7 \\
\hline 2005 & 40,0 & 1009456,3 & 161984,8 & $\mathrm{x}$ & $\mathrm{x}$ & 17994,1 & 235330,3 & 298960,1 & 295187,0 \\
\hline 2006 & 32,6 & 1447843,4 & 385996,5 & $\mathrm{x}$ & $\mathrm{x}$ & 29863,9 & 304063,4 & 432500,1 & 295419,5 \\
\hline 2007 & 33,4 & 1666020,9 & 221246,6 & 192149,0 & 29097,6 & 22275,9 & $\mathrm{x}$ & 536217,7 & 886280,7 \\
\hline 2008 & 29,0 & 1769481,7 & 130743,9 & 108453,8 & 22290,1 & 7930,7 & $\mathrm{x}$ & 1192519,5 & 438287,6 \\
\hline 2009 & 26,2 & 970915,4 & 125103,0 & 76353,0 & 48750,0 & 1997,3 & $\mathrm{x}$ & 274082,9 & 569732,2 \\
\hline 2010 & 23,9 & 1144794,1 & 183353,7 & 123529,6 & 59824,1 & 2821,8 & $x$ & 233401,9 & 725216,7 \\
\hline 2011 & 25,7 & 758002,8 & 90303,1 & 81497,3 & 8805,8 & 9179,3 & $\mathrm{x}$ & 355597,4 & 302923,0 \\
\hline 2012 & 26,1 & 1211013,9 & 144920,9 & 129336,9 & 15584,0 & 2306,1 & $\mathrm{x}$ & 420692,6 & 643094,3 \\
\hline 2013 & 25,6 & 1921431,6 & 200490,0 & 170169,0 & 30321,0 & 2066,4 & $\mathrm{x}$ & 645177,9 & 1073697,3 \\
\hline 2014 & 21,7 & 1306824,1 & 294715,4 & 225710,4 & 69005,0 & 1053,8 & $x$ & 759380,1 & 251674,8 \\
\hline 2015 & $17,3^{5}$ & 2169022,4 & 954501,6 & 888798,4 & 65703,2 & 59294,5 & $x$ & 1038716,4 & 116509,9 \\
\hline
\end{tabular}

Таблиця 2

Інноваційна діяльність промислових підприємств за регіонами

\begin{tabular}{|c|c|c|c|c|}
\hline \multirow{2}{*}{ Область } & \multicolumn{2}{|c|}{$\begin{array}{l}\text { Кількість інноваційно } \\
\text { активних підприємств }\end{array}$} & \multirow{2}{*}{$\begin{array}{c}\text { Обсяг витрат } \\
\text { на інноваційну } \\
\text { діяльність, млн.грн }\end{array}$} & \multirow{2}{*}{$\begin{array}{c}\text { Обсяг реалізованої } \\
\text { інноваційної продукції } \\
\text { усього,млн.грн }\end{array}$} \\
\hline & $\begin{array}{c}\text { усього, } \\
\text { од }\end{array}$ & $\begin{array}{l}\text { у \% до загальної кількості } \\
\text { обстежених підприємств }\end{array}$ & & \\
\hline Україна & 824 & 17,3 & 13813,7 & 23050,1 \\
\hline Вінницька & 25 & 14,7 & 575,3 & 192,4 \\
\hline Волинська & 12 & 11,5 & 65,3 & 383,6 \\
\hline Дніпропетровська & 63 & 13,0 & 7568,9 & 1145,5 \\
\hline Донецька' $^{1}$ & 28 & 11,7 & 827,6 & 4591,8 \\
\hline Житомирська & 28 & 15,5 & 32,6 & 372,3 \\
\hline Закарпатська & 14 & 10,1 & 22,5 & 583,2 \\
\hline Запорізька & 49 & 20,9 & 321,0 & 3162,3 \\
\hline Івано-Франківська & 27 & 21,6 & 92,2 & 242,0 \\
\hline Київська & 44 & 13,3 & 144,8 & 618,8 \\
\hline Кіровоградська & 25 & 24,8 & 127,7 & 354,7 \\
\hline Луганськаз & 9 & 11,3 & 24,3 & 373,2 \\
\hline Львівська & 64 & 19,3 & 277,8 & 1193,9 \\
\hline Миколаївська & 29 & 31,2 & 291,6 & 71,2 \\
\hline Одеська & 36 & 19,4 & 49,7 & 544,4 \\
\hline Полтавська & 30 & 16,2 & 128,5 & 1938,5 \\
\hline Рівненська & 13 & 10,6 & 6,9 & 67,3 \\
\hline Сумська & 23 & 19,8 & 162,3 & 1751,9 \\
\hline Тернопільська & 16 & 17,4 & 14,6 & 249,3 \\
\hline Харківська & 117 & 28,6 & 667,0 & 2742,4 \\
\hline Херсонська & 19 & 20,7 & 70,1 & 175,4 \\
\hline Хмельницька & 18 & 12,3 & 66,7 & 127,1 \\
\hline Черкаська & 25 & 17,2 & 53,5 & 289,7 \\
\hline Чернівецька & 9 & 17,0 & 18,8 & 100,0 \\
\hline Чернігівська & 15 & 13,3 & 35,0 & 95,9 \\
\hline м.Київ & 86 & 17,3 & 2169,0 & 1683,3 \\
\hline
\end{tabular}

1 Дані можуть бути уточнені. 
За результатами обстеження сформовано МІПР. Приклад фрагменту МІпР подано на рис. 1. Зокрема, у результаті формування МІПР Харківської області на основі даних, наведених у [12], до її складу увійшли 420 інноваційних технологій, із них 212 - упровадження нових технологічних процесів, 208 - освоєння інноваційних типів продукції [13].

\begin{tabular}{|c|c|c|c|c|c|}
\hline \multicolumn{6}{|c|}{ НАЙМЕНУВАННЯ НАПРЯМКІВ РОЗВИТКУ ІННОВАЦІЙНИХ ТЕХНОЛОГІЙ } \\
\hline \multicolumn{6}{|c|}{ Найменування розділу у напрямку } \\
\hline \multirow[t]{3}{*}{ № $3 / \Pi$} & \multirow{3}{*}{$\begin{array}{l}\text { № } \\
\text { під } \\
\text { роз } \\
\text { ділу }\end{array}$} & \multirow{3}{*}{$\begin{array}{c}\text { Найменування } \\
\text { інноваційної } \\
\text { технології }\end{array}$} & \multicolumn{2}{|c|}{ Інноваційне підприємство } & \multirow{3}{*}{$\begin{array}{c}\text { Область } \\
\text { використання } \\
\text { Передбачуваний } \\
\text { обсяг попиту }\end{array}$} \\
\hline & & & Вид та призначення продукції & Призначення та обсяг інвестицій & \\
\hline & & & Стан розробки & $\begin{array}{c}\text { Ефективність інвестицій (строк окупності, чиста } \\
\text { наведена вартість тощо) }\end{array}$ & \\
\hline \multicolumn{6}{|c|}{.... } \\
\hline \multicolumn{6}{|c|}{ 2.5. Високотехнологічний комплекс виробництва синтетичного моторного палива з вугілля } \\
\hline \multirow[t]{3}{*}{35} & \multirow[t]{3}{*}{2.5 .7} & \multirow{3}{*}{$\begin{array}{c}\text { Створення в } \\
\text { Україні нових } \\
\text { промислових } \\
\text { виробництв } \\
\text { синтетичного } \\
\text { моторного } \\
\text { палива. }\end{array}$} & \multicolumn{2}{|c|}{ Державне підприємство «ГИПРОКОКС» } & Нафтова і газова \\
\hline & & & $\begin{array}{c}\text { Синтетичне моторное паливо } \\
\text { (високоякісний бензин та } \\
\text { дизельне паливо) на } \\
\text { технологічній базі глибокої } \\
\text { переробки енергетичного } \\
\text { кам'яного та бурого вугілля). }\end{array}$ & $\begin{array}{c}\text { Для розробки проекту необхідно } 500 \text { тис. грн. } \\
\text { Для завершення НДДКР та виготовлення } \\
\text { пробної партії необхідно } 2 \text { роки та 1,5 млн. грн. } \\
\text { Для організації виробництва необхідно 1,2 } \\
\text { млн.грн. }\end{array}$ & \multirow[t]{2}{*}{$\begin{array}{l}\text { Обсяг реалізації, } \\
\text { що прогнозується } \\
-3,5 \text { млн. грн. у } \\
\text { рік. }\end{array}$} \\
\hline & & & НДР & $\begin{array}{c}\text { Строк окупності } 3 \text { роки, } \\
\text { ЧПВ - 1,7 млн.грн. }\end{array}$ & \\
\hline
\end{tabular}

Рис. 1. Фрагмент матриці інноваційного потенціалу регіону

Наступний етап передбачає визначення переліку інвестиційних ризиків, які можуть проявлятися на різних стадіях виробництва інноваційної продукції.

У табл. 3 наведено розподіл підприємств, керівництво яких вважає, що зазначені фактори суттєво впливали на їх рішення розвивати інноваційні проекти або стримували здійснення інноваційної діяльності упродовж 2012-2015 рр.

Таблиця 3

Розподіл неінноваційних підприємств за причинами, що перешкоджали здійсненню інновацій протягом 2012-2015 рр., \%

\begin{tabular}{l|c}
\hline Фактор & $\%$ \\
\hline Немає вагомих причин здійснювати інновації & 82,2 \\
\hline $\begin{array}{l}\text { у тому числі } \\
\text { Низький попит на інновації на ринку }\end{array}$ & 6,0 \\
\hline Через попередні інновацій & 3,9 \\
\hline $\begin{array}{l}\text { Через дуже низьку конкуренцію підприємства на } \\
\text { ринку }\end{array}$ & 3,0 \\
\hline $\begin{array}{l}\text { Відсутність хороших ідей або можливостей для } \\
\text { інновацій }\end{array}$ & 7,4 \\
\hline $\begin{array}{l}\text { Можливому впровадженню } \\
\text { перешкоджають вагомі чинники }\end{array}$ & 17,8 \\
\hline $\begin{array}{l}\text { у тому числі } \\
\text { Відсутність коштів у межах підприємства }\end{array}$ & 11,4 \\
\hline Відсутність кредитів або прямих інвестицій & 6,1 \\
\hline $\begin{array}{l}\text { Відсутність кваліфікованих працівників у рамках } \\
\text { підприємства }\end{array}$ & 1,7 \\
\hline $\begin{array}{l}\text { Труднощі в отриманні державної допомоги або } \\
\text { субсидій для інновацій }\end{array}$ & 5,8 \\
\hline Відсутність партнерів по співпраці & 1,9 \\
\hline Невизначений попит на інноваційні ідеї & 2,1 \\
\hline Занадто велика конкуренція на ринку & 4,3 \\
\hline
\end{tabular}

Наголосимо, що ці результати оцінені в цілому по країні й демонструють лише тенденції, що склалися. Ситуація може дещо відрізнятися на рівні типу діяльності й навіть на рівні підприємств, а також з огляду на те, що перелік і значущість факторів, які перешкоджають, може залежати від віку, розміру, галузі та інноваційності підприємства.

На наступному етапі залежно від типу інноваційної продукції задають коефіцієнти значущості ризиків для інвестора таким чином, щоб їх сума дорівнювала 1, а значення кожного коефіцієнта було більше о і менше 1.

Для визначення ймовірностей прояву ризиків і коефіцієнтів їх значущості на різних стадіях виробництва продукції застосовують методи експертних оцінок. 3 огляду на те, що до експертизи інноваційних технологій, як правило, залучають авторитетних науковців і фахівців, для цих цілей доцільно застосовувати метод індивідуальної оцінки «Дельфі» (Vasyl'jeva, 2010) [14]

Для інтегральної оцінки всієї сукупності інвестиційних ризиків, що з'являються на і-ой стадії виробництва інноваційної продукції, уводять величину $S_{i}$ - ступінь ризиків, яку обчислюють за таким виразом:

$$
S_{i}=\sum_{j=1}^{n} P_{i j} k_{j} \leq 1
$$

де $P_{i j}$ - імовірність прояву j-го ризику на і-й стадії виробництва інноваційної продукції; $k_{j}$ - коефіцієнт значущості $j$-го ризику для інвестора, $i=1,2, \ldots, m ; j=1,2, \ldots, n ; m$ - кількість стадій; $n$ - кількість ризиків.

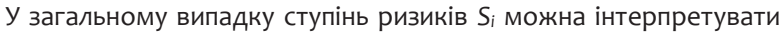
як імовірність появи на і-й стадії виробництва інноваційної продукції хоча 6 одного із $n$ ризиків із урахуванням їх значущості для інвестора.

Аналіз наявних праць із оцінки ефективності інвестиційних проектів свідчить про те, що вкладення в дослідження та інновації мають дуже високий ризик, ціна якого може становити $20 \%$ від запланованих доходів, тобто від накопиченого дисконтованого потоку готівки. Якщо вважати, що дана ціна ризику відповідає максимальному значенню ступеня ризику, то для кожної і-ї стадії виробництва можна обчислити ціну ризику $Z_{i}$, значення якої пропорційне відповідному значенню $S_{\text {i. }}$

Результати розрахунку ціни ризику (у відсотках) для різних стадій виробництва інноваційної продукції виробничого призначення на основі даних, узятих для синтетичного моторного палива (рис. 1), наведено нижче (табл. 4). 
Таблиця 4

Оцінка ціни ризику для різних стадій виробництва інноваційної продукції

\begin{tabular}{|c|c|c|c|c|c|c|c|c|c|}
\hline & & & & Ймовір & прояву ризику & & & & \\
\hline & $\begin{array}{l}\text { дії виробництва } \\
\text { аційної продукції }\end{array}$ & $\begin{array}{c}\text { Занадто } \\
\text { велика } \\
\text { конку- }\end{array}$ & $\begin{array}{c}\text { Невиз- } \\
\text { начений } \\
\text { попит на }\end{array}$ & $\begin{array}{c}\text { Труднощі } \\
\text { в отриманні } \\
\text { державної }\end{array}$ & $\begin{array}{c}\text { Відсутність } \\
\text { кваліфікованих } \\
\text { працівників }\end{array}$ & $\begin{array}{l}\text { Відсутність } \\
\text { кредитів }\end{array}$ & $\begin{array}{l}\text { Відсу- } \\
\text { тність } \\
\text { коштів }\end{array}$ & $S_{i}$ & $Z_{i}$ \\
\hline 1 & НДАКР & 0,9 & 0,9 & - & - & - & - & & \\
\hline 2 & $\begin{array}{l}\text { Дослідницьке } \\
\text { виробництво }\end{array}$ & 0,8 & 0,8 & 0,2 & 0,2 & 0,2 & 0,2 & 0,38 & 12 \\
\hline 3 & $\begin{array}{l}\text { Малосерійне } \\
\text { виробництво }\end{array}$ & 0,5 & 0,5 & 0,5 & 0,5 & 0,5 & 0,5 & 0,5 & 16 \\
\hline 4 & $\begin{array}{l}\text { Промислове } \\
\text { виробництво }\end{array}$ & 0,2 & 0,2 & 0,8 & 0,8 & 0,8 & 0,8 & 0,62 & 20 \\
\hline & $\begin{array}{l}\text { іцієнт значущості } \\
\text { ків для інвестора }\end{array}$ & 0,1 & 0,2 & 0,35 & 0,1 & 0,2 & 0,05 & 1 & 1 \\
\hline
\end{tabular}

Задача оптимального планування інвестицій у виробництво інноваційної продукції може бути сформульована із застосуванням деяких обмежень:

$$
\begin{aligned}
& \operatorname{maxNPV}=\sum_{t=1}^{1} \mathrm{NPV}_{t} X_{t}, \\
& \sum_{t=1}^{l} C_{t} X_{t} \leq Q \quad \text { - обмеження 1, } \\
& \sum_{t=1}^{l} Z_{t} X_{t} \leq D \quad \text { - обмеження 2. }
\end{aligned}
$$

У цій задачі узяті такі позначення: NPV - загальний дисконтований дохід від виробництва інноваційної продукції; $N P V_{t}$ - дисконтований дохід від виробництва $t$-го типу продукції; $C_{t}$ - обсяг інвестицій у виробництво $t$-го типу продукції; $Z_{t}$ - ціна ризику при виробництві $t$-го типу продукції; Q - загальний обсяг запланованих інвестицій; D - загальна ціна ризиків (величина неодержання доходів у разі їх прояву); змінна $X_{t}=1$, якщо $t$-у продукцію включено до складу коштів, що інвестують, і $X_{t}=0$ в іншому випадку; $t=1,2, \ldots$, , I I - кількість типів продукції.

Дана задача належить до завдань цілочислового лінійного програмування із двійковими змінними. Для їі розв'язку можна застосувати метод Ньютона, реалізований у надбудові Microsoft Excel «Пошук рішення».

Формування оптимального інвестиційного портфеля здійснюють на основі МІПР, яка містить такі характеристики кожного t-го типу інноваційної продукції, як стан розробки й інвестована стадія її виробництва, обсяг інвестицій $C_{t}$ і строки окупності $R_{t}$. При цьому можна обчислити середній дисконтований дохід $N P V_{t}$ в рік, якщо розділити обсяг інвестицій $C_{t}$, на строки окупності $R_{t}$. Тоді накопичений дисконтований дохід $N P V_{t}$, одержуваний інвестором, розраховують множенням середнього дисконтованого доходу NPV, на кількість років, що минули з моменту окупності інвестицій. Ціну ризику $Z_{t}$ визначають у відсотках від накопиченого дисконтованого доходу $N P V_{t}$. Вона залежить від стадії виробництва.

\section{Висновки}

аким чином, під час дослідження виявлено множинність Тфорсайтних варіантів інноваційного розвитку. Їх реалізацію обмежує відповідне фінансове забезпечення. Аля визначення пріоритетів інвестиційних вкладень у певний напрям розвитку інноваційного виробництва потрібно спланувати відповідні інвестиційні витрати на інноваційну продукцію. Для цього можна скористатися алгоритмом для відбору видів інноваційної продукції як об'єктів для інвестування для розвитку регіону. Послідовність визначення пріоритетів за запропонованим алгоритмом передбачає формування матриці інноваційного потенціалу регіону, оцінку інвестиційних ризиків на різних стадіях виробництва інноваційної продукції, розв'язок задачі оптимального розподілу інвестицій за типами продукції та підприємствами із урахуванням дисконтованого доходу й ціни ризиків.

Новизна дослідження полягає у алгоритмізації відбору пріоритетних для інвестування інноваційних технологій на основі матриці інноваційного потенціалу регіону.

Результати дослідження можуть бути застосовані для формування інвестиційного портфелю, що містить найбільш перспективні з економічного погляду інноваційні технології.

Перспективні теми для подальших досліджень - здійснення порівняльного портфельного аналізу інноваційних виробництв для різних галузей діяльності на основі запропонованого алгоритму.

\section{Бібліографічні посилання}

1. Bigwood, M. P. Applying "Cost of Innovation" to Technology Planning /M.P.Bigwood // Research-Technology Management. - 2000. - 43(3). - P. 39-46.

2. Kharchenko, E. Innovative potential of Russian regions: methodological aspects of analysis and development trends / E. Kharchenko, E. Alpeeva, O. Ovcharova // Procedia Economics and Finance. - 2014. - 14. - P. 313319.

3. Lowitt, K. Factors affecting the innovation potential of smallholder farmers in the Caribbean Community / K. Lowitt, G. Hickey, A. Saint Ville, K. Raeburn, T. Thompson-Colón, S. Laszlo, L. Phillip // Regional Environmental Change. - 2015. - 15(7). - P. 1367-1377.

4. Hanafizadeh, P. Portfolio design for investment companies through scenario planning / P. Hanafizadeh, A. Kazazi, A. Jalili Bolhasani // Management Decision. - 2011. - 49(4). - P. 513-532.

5. Yuregir, O. H. Solar Energy Validation for Strategic Investment Planning via Comparative Data Mining Methods: An Expanded Example within the Cities of Turkey / O. H. Yuregir, C. Sagiroglu // International J. of Photoenergy. - 2016. - 2016. P. 1-16.

6. Kleibrink, A. Monitoring innovation and territorial development in Europe: emergent strategic management / A. Kleibrink, 
C. Gianelle, M. Doussineau // European Planning Studies. 2016. - 24(8). - P. 1438-1458.

7. Lee-Mortimer, A. Managing innovation and risk / A. Lee-Mortimer // World Class Design to Manufacture. 1995. - 2(5). $-38-42$.

8. Zhang, K. Research on knowledge support technology for product innovation design based on quality function knowledge deployment / K. Zhang, W. Zhao, J. Wang, L. Chen, C. Wang, X. Guo // Advances in Mechanical Engineering. - 2016. - 8(6). - P. 1-19.

9. Rondinelli, D. National Investment Planning and equity policy in developing countries: The challenge of decentralized administration / D. Rondinelli // Policy Sciences. - 1978. Vol. 10, Issue 1. - P. 45-74.

10. Відділення прогнозно-аналітичного забезпечення інноваційної діяльності УкрIHTEІ. Форсайт в Україні [Електронний ресурс]. - Режим доступу: http://www.uintei.kiev.ua/foresight/ua/ua_foresight.php. - Заголовок з екрана.

11. Обстеження інноваційної діяльності промислового підприємства. Інноваційна діяльність промислових підприємств у 2015 р. [Електронний ресурс]. - Режим доступу: http://www.ukrstat.gov.ua/metaopus/2016/12_07_02_01_2016.htm. - Заголовок з екрана.

12. Аналітична доповідь. Економіка регіонів у 2015 р.: нові реалії і можливості в умовах започаткованих реформ. [Електронний ресурс]. - Режим доступу: http://www.niss.gov.ua/public/File/2015_nauk_an_rozrob ku/ekon_reg.pdf. - Заголовок з екрана.

13. Головне управління статистики у Харківській області. Впровадження інновацій на промислових підприємствах (2000-2015 рр.) [Електронний ресурс]. Режим доступу: http://www.kh.ukrstat.gov.ua/index.php/vprovadzhenniainnovatsii-na-promyslovykh-pidpryiemstvakh. Заголовок з екрана.

14. Васильєва, Т. А. Інноваційна складова в структурі макроекономічних індикаторів економічного розвитку [Текст] : [монографія] / Т. А. Васильєва. - Суми : ДВНЗ «УАБС НБУ», 2010. - 118 с.

\section{References}

Bigwood, M. P. (2000). Applying "Cost of Innovation" to Technology Planning. Research-Technology Management, 43(3), 39-46. doi:10.1080/08956308.2000.11671356.

Analityčna dopovid'. Ekonomika rehioniv u 2015 r.: novi realiji i možlyvosti v umovax započatkovanyx reform. Retrieved October 2016, from http://www.niss.gov.ua/public/File/2015_nauk_ an_rozrobku/ekon_reg.pdf (in Ukrainian).

Hanafizadeh, P., Kazazi, A., \& Jalili Bolhasani, A. (2011). Portfolio design for investment companies through scenario planning. Management Decision, 49(4), 513-532. doi:10.1108/00251741111126468.

Holovne upravlinnja statystyky u Xarkivs'kij oblasti. Vprovadžennja innovacij na promyslovyx pidpryjemstvax (2000-2015 rr.). Retrieved

October 03, 2016, from http://www.kh.ukrstat.gov.ua/ind ex.php/vprovadzhennia-innovatsii-na-promyslovykhpidpryiemstvakh (in Ukrainian).

Kharchenko, E., Alpeeva, E., \& Ovcharova, O. (2014). Innovative Potential of Russian Regions: Methodological Aspects of Analysis and Development Trends. Procedia Economics and Finance, 14, 313-319. doi:10.1016/s2212-5671(14)00718-7.

Kleibrink, A., Gianelle, C., \& Doussineau, M. (2016). Monitoring innovation and territorial development in Europe: emergent strategic management. European Planning Studies, doi:10.1080/09654313.2016.1181717. 24(8), 1438-1458.

Lee-Mortimer, A. (1995). Managing innovation and risk. World Class Design to Manufacture, 2(5), 38-42. doi:10.1108/09642369310095210.

Lowitt, K., Hickey, G. M., Saint Ville, A., Raeburn, K., ThompsonColón, T., Laszlo, S., \& Phillip, L. E. (2015). Factors affecting the innovation potential of smallholder farmers in the Caribbean Community. Regional Environmental Change, 15(7), 1367-1377. doi:10.1007/s10113-015-0805-2.

Obstežennja innovacijnoji dijal'nosti promyslovoho pidpryjemstva. Innovacijna dijal'nist' promyslovyx pidpryjemstv u $2015 \mathrm{r}$. Retrieved

October 05, 2016, from http://www.ukrstat.gov.ua/metao pus/2016/1-2_07_02_01_2016.htm (in Ukrainian).

Rondinelli, D. (1978). National Investment Planning and equity policy in developing countries: The challenge of decentralized administration. Policy Sciences, 10(1). 45-74. doi:10.1007/bfo0205892.

Vasyl'jeva, T. A. (2010). Innovacijna skladova v strukturi makroekonomičnyx indykatoriv ekonomičnoho rozvytku. DVNZ «UABS NBU», Cumy (in Ukrainian).

Viddilennja prohnozno-analityčnoho zabezpečennja innovacijnoji dijal'nosti UkrINTEI. Forsajt v Ukrajini. Retrieved October 03, 2016, from http://www.uin tei.kiev.ua/foresight/ua/ua_foresight.php (in Ukrainian).

Yuregir, O. H., \& Sagiroglu, C. (2016). Solar Energy Validation for Strategic Investment Planning via Comparative Data Mining Methods: An Expanded Example within the Cities of Turkey. International Journal of Photoenergy, 2016, 1-16. doi:10.1155/2016/8506193.

Zhang, K., Zhao, W., Wang, J., Chen, L., Wang, C., \& Guo, X. (2016). Research on knowledge support technology for product innovation design based on quality function knowledge deployment. Advances in Mechanical Engineering, 8(6), 119. doi:10.1177/1687814016651795. 